ISSN 2413-0877 Volume 2 (2015) 265

The 3rd International Conference on Biological Science 2013

(The 3rd ICBS-2013)

\title{
THE LICHENS DIVERSITY IN TRIANGULATION OF ALAS PURWO NATIONAL PARK, EAST JAVA
}

\author{
lin Supartinah Noer ${ }^{1}$, Joko Kusmoro², Erwan Yudiar Darussalam², \\ Dwi Nur Laksono² and Aan Abdul Hakim²
}

\author{
${ }^{1}$ Corresponding author; lin Supartinah Noer, Department of Biology, \\ Faculty of Mathematics and Natural Sciences, University of Padjadjaran, \\ Bandung, Indonesia. Tel.: +62-21-64713850; fax: +62-21-63711948. \\ ${ }^{2}$ Department of Biology, Faculty of Mathematics and Natural Sciences, University of Padjadjaran, Bandung, \\ Indonesia. \\ e-mail: iiinsnoer@unpad.ac.id or insnoer@yahoo.co.id
}

\begin{abstract}
The lichen flora of tropical areas is still much underworked Java in general and Alas Purwo in East Java for specially is no exception. Alas Purwo National Park is representative of a typical lowland tropical rain forest ecosystem in Java. . It is famous with peculiar and endemic species of plant include sawo kecik (Manilkara kauki) and manggong bamboo (Gigantochloa manggong). , beside among the other plants also ketapang (Terminalia cattapa), nyamplung (Calophyllum inophyllum), kepuh (Sterculia foetida), and keben (Barringtonia asiatica). Moreover, in lowland tropical rain forest ecosystem have reported the lichens species diversity is very high and may include over 200 species in 1 ha. There is no reported have found concerning the lichens richness in Alas Purwo. Recently preliminary study of Lichens diversity have been done at triangulation Zone Alas Purwo National Park, East Java. The lichens of the study area have not been treated comprehensively. We explored the lichenological characteristics of putative"tropical lowland cloud forest" (LCF) in a lowland area (0-20ma.s. I.) near Triangulation using macrolichens (cortocoulous species) as indicator taxa We analyzed lichen diversity on 20 trees in two 0,25 ha plots. In tropical lowland forests, corticolous green algal lichens are abundant and highly diverse. This may be related to adaptation to prevailing microenvironmental conditions including, for example, high precipitation and low light intensities. In the understory of a tropical lowland rain forest in Alas Purwo, we studied the morphology and anatomy of corticolous lichens and microcristal test. We found that from Tetrasigma sp, Serbella otodans, Hemandia feltata Baringtonia aciatika Pandanaceae Manilcara cauci Swetinia mahagoni trees there are 30 species of lichens, dominated by Dyorigma sp Graphis and Glyphis from familia of Graphidaceae and Dirinaria Physcia Pyxine Ramalina from familia of Parmeliaceae. The thallus calour was variety from Green-grey, Green-bllue, green, light green, grey, brown, dark green to orange. They have vegetative as wel as generative reproduction such as isidia, soralia, soredia, chypellae, histerothecia, perithecia, and apothecia. The lichenic acids contain such as gyrophoric acid, barbatic acid, usnic acid, atranorin, acid, divaricatic acid and lecanoric acid,
\end{abstract}

Key words: Alas Purwo, lichens and lichenic acid.

ISSN 2413-0877 @ 2015 The Authors.

Published by KnowledgeE Publishing Services This is an open access article under the CC BY-NC-ND license (http://creativecommons.org/licenses/by-nc-nd/4.0)

Selection and Peer-review under responsibility of the 3rd ICBS-2013

Doi http://dx.doi.org/10.18502/kls.v2i1.154 